\title{
Phenomena of digital divide and ways of its bridging
}

\author{
K. I. Tkachenko ${ }^{1}$, A. L. Zolkin ${ }^{2,}$, D. E. Lomakin ${ }^{5}, A . I$. Pakhomova $^{4}$, and V. V. Pomazanov ${ }^{3}$ \\ ${ }^{1}$ St. Petersburg State University, St. Petersburg, Russia \\ ${ }^{2}$ Povolzhskiy State University of Telecommunications and Informatics, Samara, Russia \\ ${ }^{3}$ Kuban State Agrarian University named after I.T. Trubilin, Krasnodar, Russia \\ ${ }^{4}$ Admiral Ushakov Maritime State University", Novorossiysk, Russia \\ ${ }^{5}$ Orel State University named after I.S. Turgenev, Orel, Russia
}

\begin{abstract}
This article is concerned with the research of digital divide challenge and its social and economic impacts. Authors review the formation of definitions and their development. Because of research, the views of famous scientists on divide, its main aspects and role in social and economic relation system are mentioned; definition of "digital divide" is reviewed; author typologies of digital divide are reviewed; five main areas of digital divide concept are highlighted; its reasons and impacts are defined. Phenomena of digital divide started to be researched extensively at the end of XX century; the following concepts can be highlighted from the main ones: total access availability, capacity development, economical change, digital public goods development, global digital cooperation. Therefore, digital divide is the newest type of divide, which is still in theoretical justification infancy; there is still no universal definition of this phenomena.
\end{abstract}

\section{Introduction}

Onrush of information and communication technologies (hereafter ICT) and improvement of information role in people's life result in significant changes in social and economic public life becoming the source not only for new possibilities but also for new challenges. Implementation process of ICT in public life is accelerator of new forms of divide, which separate people on those who have skills and possibilities to use technical tools and on those who do not. Digital divide is increased not only between the states but also between cities and countries, the haves and have-nots, the youth and the aged, disabled and healthy people. Lack of access to ICT result in malfunction of educational, healthcare and other cultural and social institutions. Modern states review the building of digital society as the base of its social and economic, political and cultural development, providing the welldirected national policy in this area.

\footnotetext{
* Corresponding author: alzolkin@list.ru
} 


\section{Problem statement}

In 2020, COVID-19 identifies the enormous divide in our society, which is in forced transformation. Over the past twelve months the significant restrictions in such areas like our communication, work, travelling, education and value creation had a major impact on our life. At the same time the technologies often came to help to mitigate or get around the restrictions. Remote work, teleconferences and increasing reliance on telehealth, remote education and e-commerce became the part of "new normal «which is still changed every day. From the beginning of coronavirus attack the digital divide start to improve from one side but it negatively effects on social life from other one. Lack of possibility to perform responsibilities remotely and on quality level and loss of income, decreasing of educational quality (and access difficulty to education for part of population) and other results including development of digital divide phenomena are the negative results of digital divide. State, society and business structures consolidated their powers for providing the possibility to use the digital devices and Internet technologies by people. The number of cloud services, services for remote work, teleconference, on-line meetings and webinar was significantly increased with moving to remote education and work was significantly increased but not all challenges were solved. Experts of Pro education Institute during express monitoring of remote education during pandemic identified that main claims are directed to technical failures of network, technical non-availability of Internet resources and lack of digital skills. So more than quarter of percent of claims were directed to the lack of digital behaviours of teachers/ lecturers. More than thirteen percent of claims were directed to availability of part of lessons on educational portals at a fee. Moreover, every ten claim was directed to lack of necessary equipment for on-line education. As a result, analysis of divide fact, its results and ways of its negotiation is the part of the actual challenges today.

\section{Research questions}

Urgency of scientific challenge associates with lack of knowledge of digital divide study in the context of economical processes as early the digital divide was studied only as sociological and partially psychological challenge. The challenge of digital divide has special interest for Russia: the average value of population digital literacy is 7.25 points from total possible, gap in educational levels is specified in generation measurement therewith the low levels of digital literacy are specified in 60 age and up audience - 6.80 points.

The following scientists put special attention on study of digital divide challenge: B. Acharya, P. Gilster, P. Himanen, M. Castells, D. Tapscott, D. Lining, G. Y. Soldatova, E. L. Vartanova, E.V. Morozova, N. V. Plotichkina, I.V. Miroshnichenko, N. A. Ryabchenko and others.

P. Gilster was among the first to develop the digital divide challenge. He for the first time presented the "Digital divide" term ans his work "Digital literacy" became the first world monograph dedicated to digital literacy and digital divide. He gave attention to skill to understand and use the information represented in various formats and wide range of sources with computers and Internet.

P. Himanen and M. Castell referred to study of "digital divide" phenomena in work "Information society and state of prosperity. Finnish model". Authors developed the theory of state information gap, which based on information economic development. Information economic connects to its network those who is of importance but disconnects those who is not of importance (therewith even more reducing their possibility to get it).

In fundamental work "Media age: economic, society and culture" M. Castell defined the unequal access to Internet as "digital gap" from sociological point of view. He emphasised 
that technological revolution covered the whole planet and united the world through information technologies.

\section{Materials and methods}

The following research tasks should be covered:

1. To study the digital divide phenomena and define its social and economic results;

2. To develop and justify the set of associated measures of government and business on reducing the digital divide in Russia.

Mutually conditioned challenges related to restriction of categorising and timing frames of research are occurred in this work with detailed study of digital divide. During study of digital divide it is required to address to the beginnings of divide origin in society, when the development of definitions was found in early works of Ancient philosopher-thinkers who endeavoured to sensemaking the dividing in society. Therewith the rich research history effects on discipline differences in study of divide as well as on terminological variety of analysed object. That is exactly why the challenges of divide should be reviewed in the light of history.

\section{Results}

There were endeavours to dispute this challenge because of its fundamental nature and ambiguity. Therefore, Ancient Greek philosopher Plato associated the problem of divide with values of freedom and justice. He identified the natural causes of people divide associated with difference in soul types established by nature and developed in process of ability training [1]. Partly, Aristotle, follower of Plato, takes the same position. He reviewed the divide as the natural conditions of people depends on their ability to act rationally, manage their fates and be responsible for their lives therefore "one men are naturally free, the others are slaves, and for last ones to be slaves is usefully and justly" [2].

New surge of interest to challenge of divide was in Modern Age when the classic political ideologies were arisen: liberalism, conservatism and socialism.

The liberals review the challenge of divide through light of freedom. They think that total elimination of divide in society is impossible; the endeavours of elimination of divide are disastrous. As English philosopher, John Locke thought people subjection to any state power is possible only on the base of mutual agreement of free, equal and independent personalities [3], i.e. on the base of social contract. Due to this, any political system assumed the violation of equality of people rights and freedoms, discrimination of one group at expense of others must be rejected.

One of the famous concepts of social divide affected on practice of digital divide diagnostic was the Marxism. Therefore, in Karl Marx's social stratification theory the main attention is placed on economic aspects, and it is clear that this opportunity (and its implications) is more brightly performed in digital divide research area. Marx described in classic way the property as the base of class differences but social stratification is unavoidable associated with economy class. Digital divide can be reviewed from this point of view as the way by which the social divide is used in digital era with application of new communication technologies.

Social stratification under Max Weber's approach includes three independent factors each of which has its own structure and therefore plays role in social ranging formation: economy class, social status and political power. The interaction between three stratification aspects corresponds to way of social structure development. Authors partly follow the Weber's views in modern representation: each of these elements might be a 
digital divide because access to new communication technologies, digital skills, computer literacy and ability to receive the profit in network facilitate the growth of political power, social status and economy impact. Due to this approach the digital divide creates the social divide in network society because it effects in social status, increasing this for those who able to use the new communication technologies, master new specialities or skills and increase the intelligent abilities Internet is powerful tool of social status support and such conclusions can be immediately identified in Weber's tradition. For example, direct connection is occurred between education (status marker and economy impact) and ability to transform the knowledge (by digital fluency) to social, economic or political impact.

The UN notes that need of reducing the digital divide is "life-or-death issue" for achievement of stable development. According to the UN's general-secretary, we still cannot totally understand what will be the social results of pandemic for world "after COVID-19". "One thing is clear: in process of recovery the digital technologies will be important more than ever before" [4], - Guterres has declared.

In the early 1990s, the "digital divide" term started to review in scientific paradigm based on knowledge gap theory and describing the digital divide through political, economic and social restrictions of access to Internet.

For the first time digital divide as a challenge was declared in report of Administration on national telecommunications and information of the US government in 1995 [5].

In Russia "digital divide" definition arisen in the early of XX century, the international seminar "Challenges of "digital divide" negotiation in Russia and CIS" was in House of Government in Novemeber, 2000. Still there is no unified definitions of abroad "digital divide" in Russian practice.

"Digital divide" term was the reason of World Summit of the UN on informational society (WSIS) in Geneva in 2003 and in Tunis in 2005. This term (and "digital gap") was widely accepted by representatives of civil society and in official documents.

Not only differences between current network access and deleted from digitalenvironment but also through practising the on-line-cooperation are meant under digital gap. For more complete characterization of reviewed challenge the types, mechanisms and theoretical models of digital divide were studied. Currently the generally accepted structure and model of digital divide are not defined. In addition, the classification of digital divide is based on traditional criteria as well as on conceptual ideas followed by ones or others authors. E. Hargittai proposed the first of such scientific typology.

In 2001, E. Hargittai highlighted two types of digital divide:

-First-order digital divide, i.e. The divide of access/ usage;

- Second-order digital divide, i.e. Differences in specific of Internet using which are became actual on the latest stages of internetization.

It was assumed that the second type of divide is possible on more wildly entry of ICT in people daily life. For our opinion, exactly this gives the base of digital divide study from different knowledge areas - sociology, economic, political science, media environment and marketing [6].

M. Hilbert developed the typology proposed by E. Hargittai; the forms defined by M. Hilbert are not completely described the digital divide conditions in XXI century.

He defines three forms of digital divide:

-Divide in access;

—Divide in ICT usage;

-Divide in Internet impact on behaviour and beliefs [7].

The same typology is actual for Vern Harper; he defines two types of digital divide in his works:

—Digital divide of access; 
- Social digital divide which includes motivation barrier, barrier of skills and knowledge and social networks barrier [8].

The problem of scientific researches obtains the highly specialized nature. $P$. DiMaggio and E. Hargittai highlighted five basic characteristics for population dividing in updated definition of digital divide:

-Availability of technical equipment and Internet connection;

-Access autonomy;

- Skills on ICT's usage;

-Availability of social support in informational technologies capturing and improving the digital literacy level;

- Tasks for informational technologies using.

Native tradition of digital divide conceptualization is mostly affected by discussions in foreign literature.

T.P. Shariphyanov and D.A. Gaynanov propose summary three-level model of digital divide which includes two sublevels of skills associated with mastery of environment and four sublevels of work with content [9].

\section{Findings}

Aspect of ICT development is reviewed as development driver in report on global development "Digital dividends", 2016 [10]. In response to new technologies, it is easier and more comfortable to communicate and receive the information; free of charge digital products and new forms of leisure time were arisen. Therefore the life of people who do not use the ICT due to different reasons (do not have access or specific skills) become more complicated. We cannot but agree as people excluded from digital environment more often lose a job, ability to participate in process of society management and become politically and economy weak. Two models of informational and digital divide can be highlighted: in interpersonal social area and global economy area (countries, regions and territories).

In report of human development of the UN, 2019, where the divide in human development in XXI century is studied, the experts highlighted two types of divide associated with extension of new technologies: divide in basic abilities and divide of access to advanced ones. Currently it is not enough to have the basic set of abilities of access to ICT because advanced ones become key determinant for self-selection of life path and provide with free actions in life. The number of concluded contracts on mobile services is part of basic abilities, and the number of concluded contracts on fixed wide access to Internet is a part of advanced ones. As far as we come in 2020 s the wide set of abilities become the basic for life in XXI century. Divide in these advanced abilities demonstrates starkly other dynamic in compare with divide in basic ones. Their lay in base of new generation of divide aspects [11]. World situation with digital divide is sufficient tragic because if it is reduced in basic ability area but it is increased in advanced ones including Russia.

In May 2020 the General Assembly of the UN developed the roadmap on digital cooperation where the recommendations of High level group on digital cooperation were described [12]. This document is basic world mark, recommendations developed direct to approach the tasks of stable development: the gender gap is reviewed, human rights through modern challenges of digital world are analysed.

There is still no unified definition of "digital divide" term but it is in common view:

"Digital divide" or "digital gap" [13] means the divide of abilities in physical, technical and social access to modern communication techniques, especially Internet. 
In the author opinion, the digital divide is cross-cutting issue which effects on all areas of social life.

In modern conditions business-structures are the main factors in digital divide negotiation but it is not possible without government support; therefore, the need of motivation of business-structures from government is existed. Authors propose the development of social business as subject of digital divide. The reason of social business underdevelopment in Russia is still the meaning of people that social problem solving is the responsibility of government. Business in all sections can improve the capacity, income; extend the markets; decrease the prices on operations and more effective control the reserves, specially the small and medium businesses, based on its large scale. Regards to consumer the informational and communication technologies can make benefits in labour policy, improvement of people prosperity and life quality. Business plays huge role in production of digital content and providing the services. Commercial players, from their side, perform the experience of network infrastructure for public programs.

For business-structures interest in minimization of digital divide the development and agitation of social business in Russia are required. If the companies will be motivated with social bonuses from government, they will have more abilities to work in this direction. The social business began to develop only recently in Russia. Nevertheless that this fact has novel character, it already takes place in one line with commercial initiatives, venture philanthropy, corporate social responsibility and welfare work. "Social business activity stands at the nexus of social and commercial sections; it is a kind of hybrid form. Now the social business is developed under uncontrolled conditions. Positions of various agencies and society regards to "social businessmen" term are different. Therefore the conditions of draft legislation is reviewed regularly."

For our opinion, the possible ways for solving the social business problem in Russia can be the following aspects as additional to common increase of "social threshold" and principles of its equal distributive between "centre" and deprived "periphery" what can become the factor of improvement of list and rate of bonuses and preferences for subjects of social business:

1. Development of social business theory;

2. Filling with real content of constitutional position about Russia as social government;

3. Legalization of social business on federal level and support to its development in critical and social important areas of activity. It is assumed to give the status of noncommercial organisation to production cooperatives as well as state enterprises, which allow to increase the prices and rates for population and economic units throughout all technological chain under condition of "open management" and establishment of control from civil society institutions for expenditure of performance results. Economic effect of such transformations is the increase of their competitiveness on internal and external markets;

4. Socialization of important enterprises in critical and social important areas of activity, first of all, in environmental management, housing and utilities infrastructure, MIC by transformation of its organizational legal forms to social business and socialy-owned enterprises.

5. Extension of direct and indirect tools of government, region and territory on politics of social business's subjects including the various bonuses and preferences in frame of indicative and contract planning with directive elements.

\section{Conclusion}

Implementation process of ICT develops unevenly that creates digital divide. Firstly, digital gap is considered as social and economic challenge. It is expressed in that the ones 
have technical abilities, materiel resources and necessary educational level for using the ICT but the others do not have access to global network due to the absence of resources on gadget purchasing, low qualification in informational technologies area. This issue is not enough studied, there is no necessary scientific base for this challenge justification. Knowledge deficit blocks the extension of individual's access to ICT.

\section{References}

1. Brockhaus and Efron Encyclopedic Dictionary, 31(61), 305 (1900)

2. Politics, Aristotle. Writings, 4, 384 (1983)

3. J. Locke, Locke J. Writings, 3, 317 (1988)

4. World can not reach the Task of stable development without reducing the digital divide: The UN's News, https://news.un.org/

5. Connecting the Nation: Libraries and Health Care Organizations in the Information Age: National telecommunications and information administration, http:// www.ntia.doc.gov/

6. T. P. Shariphyanov, D. A. Gaynanov, Regional Economics: Theory and Practice, 22, 2 (2014)

7. T. S. Martynenko, D. E. Dobrinskaya, Monitoring of public opinion: economical and social changes, 1, 171 (2021)

8. V. Yumashev, T. N. Gorobets, O. I. Admakin, G. G. Kuzminov, I. V. Nefedova, J. of Science and Technology, 9(19) (2016)

9. Abdryashitova, E. V. Gracheva, M. Yu. Kazakov, Management tools for the implementation of municipal functions in electronic form (2018), 251

10. V. Zhukovskyy, N. Zhukovska, A. Vlasyuk, A. Safonyk, 2019 IEEE 2nd Ukraine Conference on Electrical and Computer Engineering, UKRCON 2019 - Proceedings, 2019, 1179 (2019)

11. E. A. Lavrov, P. I. Paderno, A. A. Volosiuk, N. B. Pasko, V. I. Kyzenko, Proceedings of 2019 3rd Int. Conf. on Control in Technical Systems, CTS 2019, 144 (2019)

12. Zolkin, E. A. Domracheva, A. N. Losev, Yu. M. Avdeev, IOP Conference Series: Materials Science and Engineering. Krasnoyarsk Science and Technology City Hall. (2021), 12094

13. V. S. Tormozov, A. L. Zolkin, K. A. Vasilenko, 2020 Int. Multi-Conf. on Industrial Engineering and Modern Technologies (2020), 9271536 